\title{
Recombinant Interleukin-2
}

National Cancer Institute

\section{Source}

National Cancer Institute. Recombinant Interleukin-2. NCI Thesaurus. Code C587.

Any recombinant analog of endogenous interleukin-2 (IL-2), a cytokine involved in intercellular communication related to cell differentiation, proliferation, inflammation, hematopoiesis, neuronal functions, and release of hormones. IL-2 binds to and activates specific receptors, triggering expression of specific genes, and may induce T cellmediated tumor regression in some tumor types. 